\title{
SOSIALISASI TENTANG VAKSINASI COVID-19 DI KELURAHAN BIRU KECAMATAN TANETE RIATTANG KABUPATEN BONE
}

\author{
Andi Ardhia Apriliyanti ${ }^{1}$, Irfan Setiawan ${ }^{\bowtie}$, Alfiyan Ferdiyansyah $^{3}$ \\ Coreponding author: irfansetiawan@ipdn.ac.id \\ ${ }^{1}$ Manajemen Pemerintahan, Institut Pemerintahan Dalam Negeri, Sumedang, Indonesia \\ ${ }^{2}$ Prodi Manajemen Sumber Daya Manusia Sektor Publik, Institut Pemerintahan Dalam Negeri, Sumedang, \\ Indonesia \\ ${ }^{3}$ Prodi Manajemen Sumber Daya Manusia Sektor Publik, Institut Pemerintahan Dalam Negeri, Sumedang, \\ Indonesia
}

Genesis Naskah: Submitted: 06-11-2021, Revised: 17-11-2021, Accepted: 22-11-2021

\begin{abstract}
Abstrak
Kegiatan pengabdian masyarakat ini bertujuan untuk meningkatkan pemahaman vaksinasi covid-19 bagi aparat dan masyarakat di Kelurahan Biru Kecamatan Tanete Riattang Kabupaten Bone. Kegiatan ini menggunakan metode koordinasi, pengumpulan data, mengolah dan menganalisis data, pengarahan tekait peningkatan pemahaman aparat dan masyarakat, serta melakukan pemberian masker dan poster. Hasil kegiatan pengabdian masyarakat yaitu terlaksananya pengarahan tekait peningkatan pemahaman aparat Kelurahan Biru terhadap pemberian manfaat vaksin Covid-19, dan terlaksananya sosialisasi kepada masyarakat akan pentingnya melakukan vaksinasi covid dan penerapaan protokol kesehatan di rumah dan lingkungan masing-masing seperti mencuci tangan, memakai masker dan menjaga jarak.
\end{abstract}

Kata Kunci : sosialisasi, vaksinasi covid-19, peningkatan pemahaman, protokol kesehatan.

\section{SOCIALIZATION ABOUT COVID-19 VACCINATION IN THE BIRU SUBDISTRICT, TANETE RIATTANG DISTRICT, BONE REGENCY}

\begin{abstract}
This community service activity aims to improve the understanding of covid-19 vaccination for officers and the community in Biru Sub district, Tanete Riattang District, Bone Regency. This activity uses methods of coordination, data collection, processing and analyzing data, briefing on improving the understanding of officials and the community, as well as providing masks and posters. The results of community service activities are the implementation of briefings regarding increasing the understanding of the Blue Village apparatus on the provision of the benefits of the Covid-19 vaccine, and the implementation of socialization to the community about the importance of carrying out covid vaccinations and implementing health protocols at home and in their respective environments such as washing hands, wearing masks and maintaining distance.
\end{abstract}

Keywords:. socialization, covid-19 vaccination, increased understanding, health protocol

\section{Pendahuluan}

Virus Corona (covid-19) mendapat banyak perhatian khusus bagi seluruh negara sejak akhir 2020 bahkan beberapa tahun kedepan dan telah membawa pengaruh dalam berbagai aspek kehidupan. Berbagai cara yang dilakukan pemerintah dengan mengeluarkan aturan untuk menanggulanginya. aturan tersebut diberlakukan sejak bulan maret 2020,seperti lockdown yang dikenal dengan Pembatasan Sosial Berkala Besar atau PSBB (Aulia, 2020), PPKM (Napitu et al., 2021) social distancing (Anung Ahadi Pradana, 
Casman, 2020), $3 M$ atau mencuci tangan, memakai masker dan menjaga jarak (Pakaya et al., 2021). Aturan yang telah dikeluarkan pemerintah diharapkan mampu menanggulangi penyebaran Covid-19. Pemerintah juga berupaya melakukan pemberian vaksin untuk meningkatkan imun tubuh masyarakat.

Sesuai Instruksi Presiden, isi salah satu penyampaiaannya bahawa untuk seluruh jajaran kabinet, lembaga dan dari pemerintahan daerah agar memprioritaskan program yang direncanakan oleh pemerintah yaitu program vaksinasi dengan menggunakan anggaran tahun 2021 (Presiden Republik Indonesia, 2020). Pemberian vaksin Covid-19 yang diberikan kepada masyarakat itu secara gratis dan tidak perlu untuk membayar vaksin tersebut. Program vaksinasi Covid-19 di Indonesia sudah dilakukan oleh pemerintah. Secara serentak dan bertahap diberikan terlebih dahulu kepada tenaga kesehatan serta tenaga penunjang kesehatan di 34 provinsi di Indonesia dengan memprioritaskan kelompok masyarakat tertentu yang memiliki risiko tertular Covid-19 yang lebih tinggi dan memenuhi syarat. Vaksin ini sudah mendapatkan izin dari Badan Pengawas Obat dan Makanan (BPOM) serta fatwa halal dari Majelis Ulama Indoinesia (MUI). Pemerintah juga sedang gencar melakukan sosialisasi pentingnya vaksinasi ini untuk memutus rantai penyebaran covid 19 (Akbar, 2021), termasuk pemerintah daerah yang ikut mengsosialisasikan dan menyukseskan Program vaksinasi Covid-19 sesuai instruksi presiden tersebut.

Sehubungan dengan itu, Berdasarkan Peraturan Bupati Bone tentang penerapan disiplin dan penegakan hukum protokol kesehatan sebagai upaya pencegahan dan pengendalian Covd-19 di Kabupaten Bone (Pemerintah Kabupaten Bone, 2020). Pada tanggal 3 Februari 2021 Pemerintah Kabupaten bone melaksanakan program vaksinasi dengan mengusung tema "Wujudkan masyarakat kabupaten Bone yang sehat dan produktif dengan vaksinasi Covid-19". Vaksinasi tersebut dilakukan secara serentak di masing-masing kecamatan serta kelurahan dengan tetap memperhatikan dan mematuhi protokol kesehatan. Meskipun program vaksinasi sudah dilakukan, adanya berita negative terkait vaksin yang menyebabkan beberapa masyarakat tidak ingin divaksinasi untuk sementara waktu. khusus dikelurahan biru, sebagian masyarakat masih takut untuk disuntik karena vaksin yang diberikan, akan menyebabkan mereka cepat sakit dan tibulnya beberapa masalah kesehatan. isu ini menjadi permasalahn yang dirasakan oleh masyarakat kelurahan biru. rasa kewaspadaaan yang tinggi yang dimiliki oleh masyarakat akan kesehatan sangatlah baik tetapi isu ini dianggap meresahkan yang mempengaruhi pola pikir dan tindakan akan respon masyarakat terhadap pemberin vaksin yang akan diberikan oleh pemerintah.

\section{Metode Pelaksanaan}

Kegiatan yang akan dilakukan oleh penulis, dengan beberapa tahapan untuk meningkatkan pemahaman aparat terkait vaksinasi Covid-19 di Kelurahan Biru Kecamatan Tanete Riattang Kabupaten Bone Provinsi Sulawesi Selatan. Pertama, penulis melakukan koordinasi dengan Lurah Biru beserta pegawai di kelurahan biru 
untuk melaksanakan kegiatan kepada aparat kemudian kelurahan Biru menentukan waktu dan tempat pelaksanaan. Penulis juga berkoordinasi dengan petugas kesehatan serta bagian aparat pengamanan terkait materi penulis yang lebih rinci dan yang ikut serta dalam kegiatan tersebut. Kedua, Penulis melakukan pengumpulan data, melalui wawancara kepada aparat, dan studi literatur berkaitan dengan manfaat dan teori pendukung terkait manfaat vaksin Covid-19. Ketiga, Penulis mengolah dan menganalisis datadata yang sudah dikumpulkan pada tahap sebelumnya. Teknik pengolahan data ini,akan menghasilkan analisis yang merujuk pada peingkatan pemahaman vaksin Covid-19 bagi aparat Kelurahan Biru. Keempat, Pengarahan tekait peningkatan pemahaman aparat yang merupakan kegiatan utama dalam hal peningkatan pemahaman terkait pemberian vaksinasi Covid-19 kepada aparat di wilayah kelurahan biru sesuai Instruksi Presiden Tahun 2020 serta Peraturan kabupaten Bone No. 37 tahun 2020 tentang Disiplin dan Penegakan Hukum Protokol Kesehatan sebagai Upaya Pencegahan dan Pengendalian Covid-19. Kemudian kelima, Pemberian masker dan poster vaksinasi Covid-19 kepada Kantor Kelurahan Biru. Pada tahap ini, poster diberikan kepada kantor kelurahan biru yang langsung diberikan kepada Lurah Biru terkait Pemberian serta manfaat vaksin Covid-19. Kegiatan ini merupakan tahapan akhir dalam pemberian peningkatan pemahaman kepada aparat dan masyarakat yang berbeda pandangan terkait vaksinasi.

\section{Hasil dan Pembahasan}

Pengarahan tekait peningkatan pemahaman aparat Kelurahan Biru terhadap pemberian manfaat vaksin Covid-19

Pelaksanaan kegiatan dilakasanakan pada hari senin, 08 Maret 2021 bertempat di kantor Kelurahan Biru pada pukul 10.00 WITA sampai selesai dengan tetap mematuhi aturan protkol kesehatan sesuai dengan Peraturan Bupati Bone Nomor 37 Tahun 2020 tentang penerapan disiplin dan penegakan hukum protokol kesehatan sebagai upaya pencegahan dan pengendalian Covd-19. Koordinasi terlebih dahulu dilaksanakan sebagai langkah pertama untuk melaksanakan kegiatan serta dari kantor Kelurahan Biru untuk memfasilitasi kegiatan in, sebagaimana gambar berikut:

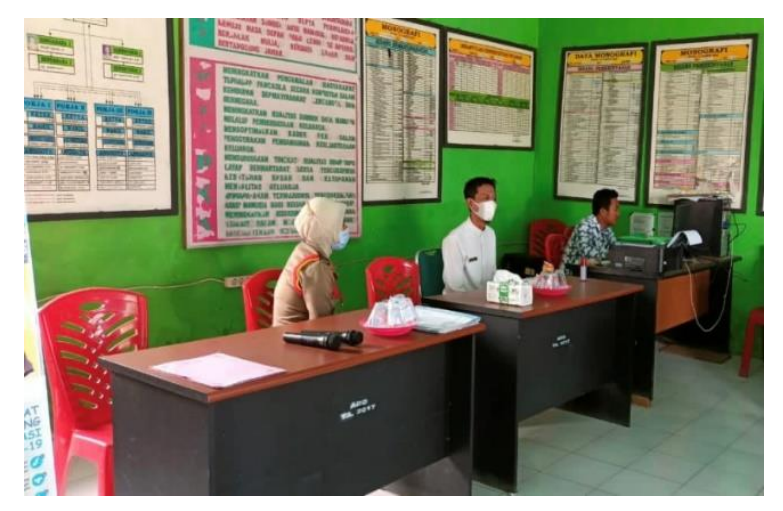

Gambar 1. Koordinasi bersama pegawai Kantor Kelurahan Biru

Lurah biru bersama penulis sebagai narasumber terkait peningkatakan pemahaman pemberian manfaat vaksin Covid-19 bagi kesehatan tubuh kepada masyarakat kelurahan biru. Pemahaman yang diberikan berupa dampak positif yang dirasakan setelah masyarakat mendapatkan suntikan vaksin covid-19. Pada kegiatan ini didapati beberapa alasan dari 
masyarakat bahwa "kami tidak mengetahui efek samping vaksin atau apakah vaksin itu"Masyarakat 1. "jika memiliki efek samping,pihak siapa yang akan bertanggung jawab dengan biaya pengobatannya dikarekan memiliki trauma takut akan jarum suntik"-masyarkat 2. Pertanyaan tersebut kami rampung serta menyimpulkan bahwa sebetulnya masyarakat menolak itu karena ragu dari efek samping yang akan dirasakan saat setelah divaksinasi sehingga gunanya kegiatan ini untuk membuka lebih luas pengetahuan dan pemahamana yang benar akan manfaat vaksin kepada masyarakat.

Masyarakat dapat secara langsung menyampaiakan alasan dari penolakan dan apa yang dirasakan sampai saat ini. Kegiatan ini juga mendatangkan tim kesehatan covid-19 yang tentunya yang terpercaya dan akurat. Setelah kegiatan ini dilaksanakan foto bersama dengan beberapa pihak yang terlibat dalam pelaksanaan kegiatan tersebut.

\section{Pemberian masker secara gratis dan poster} vaksinasi Covid-19 kepada aparat dan masyarakat di Kelurahan Biru

Selesainya kegiatan langsung dilaksanakan pemberian poster dan diterima oleh Lurah Biru serta dibeberapa tempat dilakukan pemasangan poster sesuai dengan arahan Lurah Biru. Terlihat pada gambar dibawah.

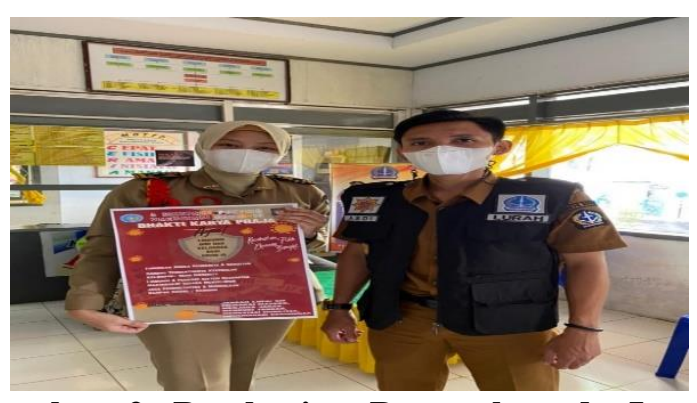

Gambar 2. Pemberian Poster kepada Lurah biru

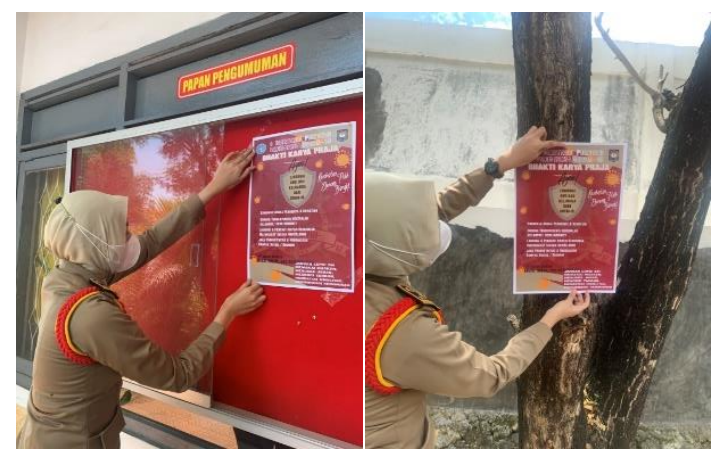

Gambar 3. Pemasangan poster

Selain kegiatan tersebut, juga dilakukan kegiatan sosialisasi dan pemberian masker kepada masyarakat yang datang ke Kantor Kelurahan Biru. Sosialisasi melalui pendekatan person to person terkait akan peningkatan pemahaman manfaat vaksin diberikan kepada masyarakat agar selanjutnya dapat dishare kembali kepada masyarakat lain.

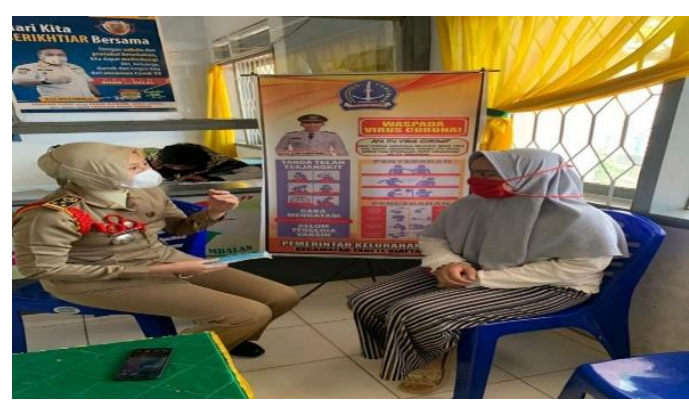

Gambar 4. Pembagian masker

Kegiatan sosialisasi bertujuan agar masyarakat semakin mengerti akan pentingnya 
melakukan vaksinasi covid untuk membentuk kekebalan kelompok di lingkungan masyarakat. Selain itu juga disosialisasikan untuk menerapkan protokol kesehatan di rumah dan lingkungan masing-masing seperti mencuci tangan, memakai masker dan menjaga jarak.

\section{Kesimpulan}

Kegiatan Peningkatan pengetahuan masyarakat Kabupaten Bone khususnya Kelurahan Biru tentang Covid-19 terkait vaksinasi covid berjalan dengan baik. Sosialisasi vaksinasi covid di masyarakat dapat berfungsi sebagai penerapan protokol kesehatan yang dapat diterapkan dalam beraktivitas di luar rumah. Adanya Stigma Negative yang tumbuh dan berkembang dimasyarakat terkait vaksin menyebabkan kegaduhan. Diharapkan Jangan ada lagi stigma negative terkait vaksin itu berbahaya untuk tubuh yang berkembang dimasyarakat. sebagai masyarakat yang cerdas akan pengetahuan yang tinggi agar bersama-sama melawan stigma negative dan menyebarkan informasi akurat, membantah berita palsu/hoaks. Berita positif juga perlu disebarluaskan seperti jumlah pasian yang sembuh, program bantuan kepada masyarakat terinfeksi Covid-19. serta memberikan dukungan semangat bantuan, apresiasi kepada pasien Covd19 dan para tenaga kesehatan.

\section{Daftar Pustaka}

Akbar, I. (2021). Vaksinasi Covid-19 dan Kebijakan Negara: Perspektif Ekonomi Politik. Jurnal Academia Praja, 4(1), 244-254. https://ejournal.fisip.unjani.ac.id/ index.php/jurnal-academia-
Anung Ahadi Pradana, Casman, N. (2020). Pengaruh Kebijakan Social Distancing pada Wabah COVID-19 terhadap Kelompok Rentan di Indonesia. Jurnal Kebijakan Kesehatan Indonesia : JKKI, 9(2), 61-67. https://jurnal.ugm.ac.id/jkki/article/view/55575

Aulia, S. T. (2020). Diskursus Penanganan Covid-19 Oleh Pemerintah Pusat Dan Daerah: Efektifkah Kebijakan Pembatasan Sosial Berskala Besar (PSBB) Diterapkan? https://fh.unpad.ac.id/diskursus-penanganancovid-19-oleh-pemerintah-pusat-dan-daerahefektifkah-kebijakan-pembatasan-sosialberskala-besar-psbb-diterapkan/

Napitu, U., Corry, \& Matondang, M. K. D. (2021). Sosialisasi pembatasan pelaksanaan kegiatan masyarakat (PPKM) mikro di kelurahan bah Kapul. Community Development Journal, 2(2), 232-241.

https://journal.universitaspahlawan.ac.id/index.p hp/cdj/article/view/1698/1272

Pakaya, R., Ramadhani, F., Hanapi, S., Deisi Badu, F., \& Iyou, I. (2021). Penerapan 3M Dalam Upaya Pencegahan Penularan Corona Virus Disease Di Desa Mohiloyo. Jurnal Pengabdian Kepada Masyarakat Universitas Gorontalo, 3(1), 34-38. https://jurnal.unigo.ac.id/index.php/insancita/arti cle/view/1415/644

Pemerintah Kabupaten Bone. (2020). Peraturan Bupati Bone Nomor 37 Tahum 2020 Tentang Penerapan Disiplin dan Penegakan Hukum Protokol Kesehatan Sebagai Upaya Pencegahan dan Pengendalian Corona Virus Disease 2019 di Kabupaten Bone (pp. 1-7). https://bone.go.id/2020/09/07/peraturan-bupatibone-tentang-penegakan-hukum-protokolkesehatan/

Presiden Republik Indonesia. (2020). Instruksi Presiden (INPRES) Nomor 6 Tahun 2020 tentang Peningkatan Disiplin dan Penegakan Hukum Protokol Kesehatan Dalam Pencegahan dan Pengendalian Corona Virus Disease 2019. 2019(031242),

6.https://peraturan.bpk.go.id/Home/Details/1426 25/inpres-no-6-tahun-2020 